\title{
Photovoltaic Manufacturing Technology Phase 1
}

NREL/TP--214-4482

DE92 001169

\section{Final Subcontract Report \\ 9 January 1991 - 14 April 1991}

M. J. Stern

Utility Power Group

Chatsworth, California

NREL technical monitor: R. Mitchell

National Renewable Energy Laboratory

(formerly the Solar Energy Research Institute)

1617 Cole Boulevard

Golden, Colorado 80401-3393

A Division of Midwest Research Institute Operated for the U.S. Department of Energy under Contract No. DE-AC02-83CH10093

Prepared under Subcontract No. XC-1-10057-6

November 1991

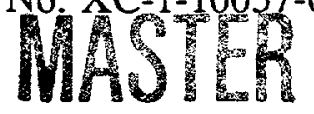


This publication was reproduced from the best available camera-ready copy submitted by the subcontractor and received no editorial review at NREL.

\title{
On September 16, 1991 the Solar Energy Institute was designated a national laboratory, and its name was changed to the National Renewable Energy Laboratory.
}

\section{NOTICE}

This report was prepared as an account of work sponsored by an agency of the United States government. Neither the United States government nor any agency thereof, nor any of their employees, makes any warranty, express or implied, or assumes any legal liability or responsibility for the accuracy, completeness, or usefulness of any information, apparatus, product, or process disclosed, or represents that its use would not intringe privately owned rights. Reference herein to any specific commercial product, process, or service by trade name, trademark, manufacturer, or otherwise does not necessarily constitute or imply its endorsement, recommendation, or favoring by the United States government or any agency thereof. The views and opinions of authors expressed herein do not necessarily state or reflect those of the United States government or any agency thereof.

\author{
Printed in the United States of America \\ Available from: \\ National Technical Information Service \\ U.S. Department of Commerce \\ 5285 Port Royal Road \\ Springfield, VA 22161 \\ Price: Microfiche A01 \\ Printed Copy $\mathrm{AO3}$
}

Codes are used for pricing all publications. The code is determined by the number of pages in the publication. Information pertaining to the pricing codes can be found in the current issue of the following publications which are generally available in most libraries: Energy Research Abstracts (ERA); Government Reports Announcements and Index (GRA and I); Scientific and Technical Abstract Reports (STAR); and publication NTIS-PR-360 available from NTIS at the above address. 


\section{DISCLAIMER}

Portions of this document may be illegible electronic image products. Images are produced from the best available original document. 
TABLE OF CONTENTS

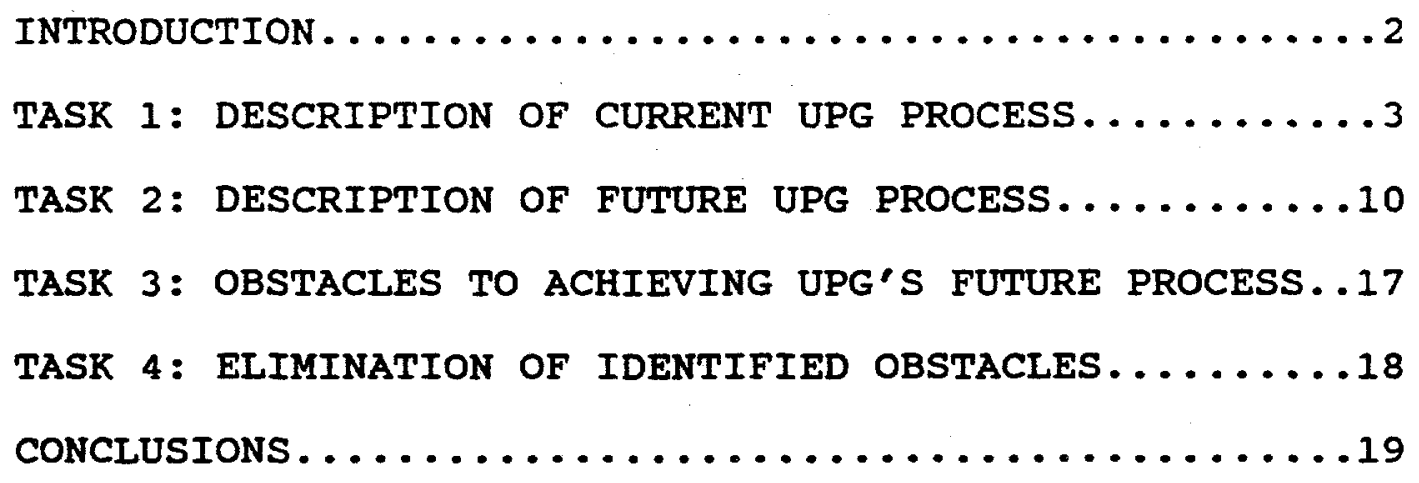

INTRODUCTION

This Photovoltaic Manufacturing Technology (PVMaT) Phase I Final Report quantifies the current costs involved in UPG's manufacture of PV modules (TASK 1), and projects future manufacturing costs (TASK 2) if a suggested plan for eliminating identified technical obstacles (TASK 3 ) is acted upon (TASK 4).

Manufacturing cost, as used in this report, is defined as the sum of those cost elements directly related to the manufacture of PV modules. Indirect cost elements such as those associated with R\&D, G\&A, engineering, marketing, and their corresponding overhead expenses, are not included in this report's calculation of manufacturing cost. Although such omissions would be ludicrous in a profit/loss analysis of a PV module manufacturing business, it is nonetheless appropriate in this analysis of the effect of manufacturing technology on the cost of PV modules. 
Utility Power Group (UPG) operates a photovoltaic (PV) module manufacturing facility capable of producing single or double junction amorphous silicon alloy based modules. Modules are fabricated on glass superstrates of 0.10 square meters in area, with annual production capacities of 30,000 and 60,000 for double and single junction modules respectively.

The manufacture of these modules requires eighteen distinct processing steps, each of which will be briefly described and analyzed in terms of manufacturing cost. Actual costs presented are for double junction modules on a per module basis, and were derived from data taken over a nine month production period with an average combined electrical and mechanical yield of $92 \%$. Materials' cost includes freight and in-house handing, while labor cost includes payroll taxes, fringe benefits, and module inspection time at each process step. Labor is divided into two categories, I and II, where Labor $I$ is production level personnel at $\$ 15 /$ hour and Labor II is technical level personnel at $\$ 23 /$ hour. Capital cost is not considered since all manufacturing equipment is fully paid for and depreciated. Operating expense includes expendable supplies and utilities. Significant cost elements are shown in parenthesis.

\section{Process Step 1: Pattern Front Transparent Conductor}

UPG purchases the superstrate glass with the front transparent conductor already deposited. The purchase cost of the glass is included in this process step. A semiautomatic mechanical abrasion system is utililized to pattern (remove) transparent conductor materials for cell (interconnect) formation and module (perimeter) isolation.

Cost Analysis:

Materials Operating Expense Labor I
$\$ 2.50$

$\$ 0.55$

$\$ 0.50$
(Coated glass)

(Abrasives, fixtures, nitrogen)

\section{Process Step 2: Clean}

A modified in-line printed circuit board washer performs this cleaning process in which all excess abrasive materials are removed from the surface of the glass, and the surface is prepared for subsequent processing.

Cost Analysis:

Operating Expense $\begin{aligned} & \$ 0.32 \\ & \text { Labor I }\end{aligned} \quad$ (Deionized water, detergent)
$\$ 0.25$


Process Step 3: Screen Print Conductive Paste

Conductive paste is applied to the glass via a semiautomatic screen printing process to permit cell series interconnection (bridge conductors), to allow collection of the module's electric current (bus bars), and to facilitate the connection of electrical terminations. The paste is essentially composed of silver particles and glass frit, a combination that forms a rugged, solderable, and conductive material when fired in a furnace at the appropriate temperature.

Cost Analysis:

Materials Operating Expense Labor I
$\$ 0.75$ (Paste)

$\$ 0.13$

$\$ 0.25$ (Screens, chemicals, wipes)

Process Step 4: Fire

As described in Process step 3, the conductive paste requires a heat treatment step in which the paste is fired, thereby solidly linking the silver and glass components together in a rigid matrix. A batch type furnace is utilized in this step.

Cost Analysis:

$\begin{array}{ll}\text { Operating Expense } & \$ 0.20 \\ \text { Labor I } & \$ 0.05\end{array} \quad$ (Electricity)

Process Step 5: Screen Print Maskant Paste

Maskant paste is applied to the module with the same screen printing machine used to apply the conductive paste. The purpose of the maskant is to form a removable "mask" over those areas of the module where rear conductive materials are not to remain. This paste is composed of organic and inorganic materials which, when properly heat treated, create a solid and continuous barrier to deposition with only temporary adhesion to the module surface.

Cost Analysis:

Materials Operating Expense Labor I
$\$ 0.25$

$\$ 0.13$

$\$ 0.25$
(Paste)

(Screens, chemicals, wipes)

Process Step 6: Bake

The maskant paste heat treatment process is called bake to differentiate it from the conductive paste fire process. 
Although the same furnace is utilized for both processes, their time/temperature profiles are completely different.

Cost Analysis:

$\begin{array}{lll}\text { Operating Expense } & \$ 0.10 \\ \text { Labor I } & \$ 0.05\end{array}$ (Electricity)

Process Step 7: Deposit Amorphous Silicon Alloys
Process Step 8: Pattern Amorphous Silicon Alloys
Process Step 9: Deposit Rear Conductor

All three of these steps are performed sequentially within an automated thin film materials processing system. Due to the sensitive nature of electrically active thin film materials, modules do not exit the system's computer controlled vacuum environment prior to the deposition of the final thin film layer, the rear conductor. The amorphous silicon alloy material layers are deposited via a plasma enhanced chemical vapor deposition process, and are mechanically patterned (removed) to provide electrical continuity between the bridge conductors and the rear conductor, thus forming the module interconnects. The rear conductor, an alloy of aluminum, is deposited via a sputtering process.

Cost Analysis:

$\begin{array}{lll}\begin{array}{l}\text { Materials } \\ \text { Operating Expenses }\end{array} & \begin{array}{l}\$ 2.26 \\ \$ 1.90\end{array} & \begin{array}{l}\text { (Compressed gases, target) } \\ \text { (Compressed gases, elec- } \\ \text { tricity) }\end{array} \\ \text { Labor II } & \$ 3.85 & \end{array}$

Process Step 10: Anneal

Annealing the modules in air after thin film deposition enhances their electrical performance and facilitates the removal of the maskant. A small batch oven is utilized for this operation.

Cost Analysis:

$\begin{array}{lll}\text { Operating Expenses } & \$ 0.05 \\ \text { Labor I } & \$ 0.10\end{array}$ (Electricity)

Process Step 11: Remove Maskant

A modified industrial glass sheet washing machine is utilized to strip off the maskant material and the unwanted rear conductor layer on top of it. This water based process also serves to prepare the module surface for future encapsulation processes. 
Cost Analysis:

Operating Expenses $\$ 0.20$
$\$ 0.05$$\quad$ (Deionized water)

Process Step 12: Remove Shunts

Shunts are deleterious electrically conductive paths between the front transparent conductor and the rear conductor. These paths are typically due to peaks of transparent conductor material piercing through the amorphous silicon alloy layers, or to small holes in the amorphous silicon layers, both of which permit the rear conductor to contact the front conductor. Removal of the electrical shunts is accomplished by passing sufficient electrical current through them to cause vaporization of the conductive path without damaging the surrounding device material.

Cost Analysis:

Labor I $\$ 0.20$

Process Step 13: Attach Ribbon Conductor

Collection of the module's generated electric current is the responsibility of the bus bars, but a high conductivity link is needed to connect the bus bars to the module's external terminals. This link is in the form of a tin plated copper ribbon (Flat wire) which is soldered along the length of the bus bar and passed through a terminal hole in the back glass prior to lamination. This step is performed manually.

Cost Analysis:

Materials Labor I \$0.15 (Ribbon, solder)

$\$ 2.20$

Process step 14: Laminate

To permit a twenty year life in an outdoor environment, the PV module must be encapsulated within materials which are impervious to moisture, abrasion, and natural temperature variations. UPG's module design incorporates glass/glass construction in which a sheet of tempered glass is laminated to the module superstrate glass sheet with a quasi-thermosetting (EVA) plastic interlayer. Although the module edge seal remains nonhermetic, an isolated perimeter border region provides an exceptionally rugged edge seal. The lamination process involves subjecting the glass/EVA/glass package to heat and mechanical pressure while in a vacuum environment. The vacuum insures no air will be trapped in the module lamination, the heat softens the EVA to facili- 
tate "wetting" to the glass surfaces, and the mechanical pressure uniformly distributes contact between the glass sheets and the EVA. A semiautomatic lamination machine performs this operation.

Cost Analysis:

Materials

Operating Expense Labor I
$\$ 2.90$

$\$ 0.08$

$\$ 1.95$
( Tempered glass, EVA)

(Release paper, electricity)

Process step 15: Terminate

Every PV module requires at least one positive and one negative electrical terminal. These terminals are the only violation of the module's encapsulation integrity, and therefore are a critical component in providing module reliability. The ribbon conductor passes through a small hole in the tempered glass sheet, and is isolated from the outside environment by a silicone rubber gasket. The actual terminal connector is bonded to the tempered glass with a silicone rubber adhesive which serves to mechanically isolate the terminal connector from the ribbon conductor. The terminate step is performed manually.

Cost Analysis:

Materials

Labor I
$\$ 0.25$

$\$ 2.10$

(Terminals, silicones, solder)

Process Step 16: Cure

To achieve maximum adhesion between the glass surfaces and EVA, and between the glass surface,terminal and silicone rubber adhesive, a heat treatment operation called the cure step is required. The cure step is performed within a large batch oven.

Cost Analysis:

$\begin{array}{ll}\text { Operating Expense } & \$ 0.10 \\ \text { Labor I } & \$ 0.25\end{array}$ (Electricity)

\section{Process Step 17: Final clean}

During the laminate, terminate, and cure steps, the modules may receive excess EVA, silicone rubber, and other contamination on their surfaces due to manual processing. Final clean involves the manual removal of ali excess and undesirable materials from the module's surfaces.

- Cost Analysis:

$\begin{array}{ll}\text { Operating Expenses } & \$ 0.05 \\ \text { Labor I } & \$ 0.60\end{array} \quad$ (Cleaning supplies)


Process step 18: Test

The electrical output characteristics of each module are determined in this step, which utilizes a semiautomatic solar simulation system.

Cost Analysis:

Labor I $\$ 0.25$

On the following page, Table 1 provides a listing of each process step, and Table 2 provides a summary of the cost analyses. 
TABLE 1

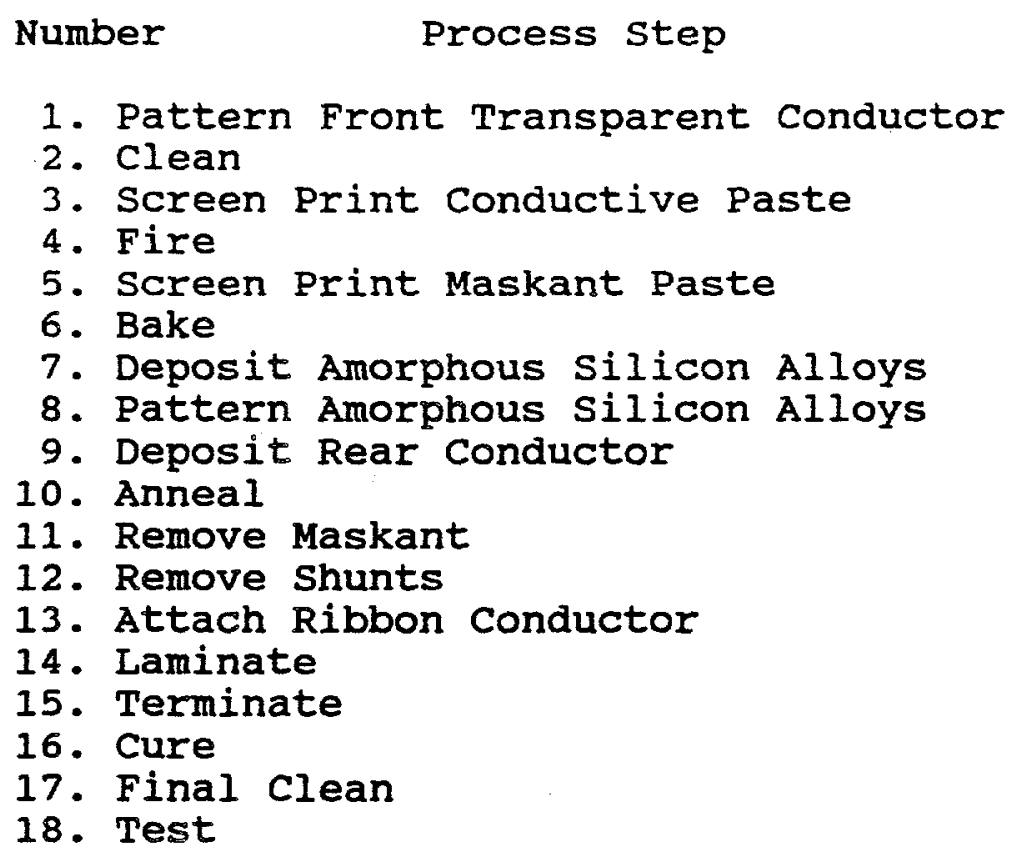

TABLE 2

SUMMARY COST ANALYSIS

\begin{tabular}{|c|c|c|c|c|}
\hline $\begin{array}{l}\text { Process } \\
\text { Step }\end{array}$ & Material & $\begin{array}{c}\text { Operating } \\
\text { Expense }\end{array}$ & Labor & Total \\
\hline $\begin{array}{l}1 \\
2 \\
3 \\
4 \\
5 \\
6 \\
7,8,9 \\
10 \\
11 \\
12 \\
13 \\
14 \\
15 \\
16 \\
17 \\
18\end{array}$ & $\begin{array}{l}\$ 2.50 \\
\$ 0.75 \\
\$ 0.25 \\
\$ 2.26\end{array}$ & $\begin{array}{l}\$ 0.55 \\
\$ 0.32 \\
\$ 0.13 \\
\$ 0.20 \\
\$ 0.13 \\
\$ 0.10 \\
\$ 1.90 \\
\$ 0.05 \\
\$ 0.20 \\
\$ 0.08 \\
\$ 0.10 \\
\$ 0.05\end{array}$ & $\begin{array}{l}\$ 0.50 \\
\$ 0.25 \\
\$ 0.25 \\
\$ 0.05 \\
\$ 0.25 \\
\$ 0.05 \\
\$ 3.85 \\
\$ 0.10 \\
\$ 0.05 \\
\$ 0.20 \\
\$ 2.20 \\
\$ 1.95 \\
\$ 2.10 \\
\$ 0.25 \\
\$ 0.60 \\
\$ 0.25\end{array}$ & $\begin{array}{l}\$ 3.55 \\
\$ 0.57 \\
\$ 1.13 \\
\$ 0.25 \\
\$ 0.63 \\
\$ 0.15 \\
\$ 8.01 \\
\$ 0.15 \\
\$ 0.25 \\
\$ 0.20 \\
\$ 2.35 \\
\$ 4.93 \\
\$ 2.35 \\
\$ 0.35 \\
\$ 0.65 \\
\$ 0.25\end{array}$ \\
\hline & $\$ 9.06$ & $\$ 3.81$ & $\$ 12.90$ & $\$ 25.77$ \\
\hline
\end{tabular}

$\begin{array}{lllll}\text { Total } & \$ 9.06 & \$ 3.81 & \$ 12.90 & \$ 25.77\end{array}$

The manufacturing cost total of $\$ 25.77$ per module represents a per watt manufacturing cost of $\$ 6.44$ based upon an average stabilized total area conversion efficiency of $4.0 \%$. 
As an electricity generating technology, photovoltaic modules and systems are evaluated financially in terms of their cost in dollars per watt $(\$ / W)$ of electricity produced. Given the fact that a range of competing generation technologies exist, a reduction in the cost of $\mathrm{PV}$ modules will result in an increase in market size. For the PV manufacturer, the $\$ / W$ cost of PV modules is obtained by dividing the cost per module ( $\$ /$ Module) by the average number of watts per module (W/Module) produced. Therefore, the $\$ / W$ cost of $P V$ modules can only be reduced by one of the following methods:

1. Decrease the manufacturing cost per module

2. Increase the average number of watts per module

The first method is the focus of UPG'S PVMaT effort, and is addressed in this report. The second method requires the development of higher performance thin film materials, an activity which is research rather than manufacture oriented. UPG has presented a detailed research plan to SERI to increase the average number of watts per module, and all process modifications which may be derived from this plan are compatible with UPG'S current and future manufacturing equipment.

Efficiency is the key to decreasing the manufacturing cost per module, but labor efficiency, capital efficiency, and materials efficiency should not be confused with sunlight conversion efficiency. PV module manufacturing efficiency is essentially a measure of how many marketable modules are produced for each dollar of labor, capital, and materials expended. The objective of TASK 2 is to identify and describe potential efficiency improvements to UPG'S manufacturing technology, and the effect of these improvements on manufacturing cost.

A major element in increasing manufacturing efficiency is economy-of-scale. Economy-of-scale relates to the optimum production volume in terms of labor, capital, and materials. The material cost per unit of a particular item decreases as the number of items purchased increases. This relationship is not linear, however, and it typically yields diminishing returns beyond "truckload" quantities. Capital equipment cost per unit produced decreases as the size and throughput of the equipment increases, but this effect eventualiy levels off. Although labor is not usually considered in terms of economy-of-scale, it is appropriate in this analysis because it is necessary to efficiently utilize technically skilled labor. For example, if one process engineer is required to monitor a single process step., it is most efficient to maximize the step's throughput to the highest level the engineer can effectively monitor.

UPG'S future process is based upon a production rate of 250,000 modules per year. Module area will be 0.5 square meters $(50 \mathrm{~cm} . \times 100 \mathrm{~cm}$.$) and annual production in terms of watts will$ range from 5MW (current stabilized total area conversion efficiency of $4 \%$ ) to $12.5 \mathrm{MW}$ (post research stabilized total area conversion efficiency of 10\%). This increase in module area and 
production rate will provide $95 \%$ of the potential cost reduction attributable to economy-of-scale factors.

Economy-of-scale factors alone, however, are not sufficient to reach UPG's manufacturing cost reduction goals. Manufacturing technology improvements such as simplification and consolidation of several process steps and implementation of process automation concepts are required.

The following description of UPG'S future process and its cost analysis will be presented in the same form as was that of the current process (TASK 1) except that a description of a particular process step will not be included if that step is identical to that in the current process. Only Labor II level personnel will be utilized in the future process, and the cost will increase to $\$ 30.00$ per hour. Although capital cost will not be analyzed in detail in this report, depreciation expense of the future process' equipment using a ten year straight line method, would equal $\$ 1,200,000$ per year ( $\$ 4.80$ per module). The total equipment cost projection is based upon a combination of vendor quotations and UPG estimates for specific items of custom designed equipment. All material cost projections for UPG's future process were derived from vendor quotations for delivery under annual blanket orders.

\section{Process Step 1: Prepare Module Glass}

Glass sheets will be purchased with the transparent conductor coating applied. At UPG, these sheets will be cut to module size and edge polished by a fully automatic glass sheet processing system. The purchase cost of the glass sheet is allocated to this step.

Cost Analysis:

$\begin{array}{ll}\text { Materials } & \$ 8.10 \\ \text { Operating Expense } & \$ 0.20 \\ \text { Labor II } & \$ 0.25\end{array}$

(Coated glass sheet) (Cutting, polishing wheels)

\section{Process Step 2. Pattern Front Transparent Conductor}

A fully automatic modified screen printing system will remove the transparent conductor material for cell formation by an electrochemical etching process. This process is superior to a mechanical abrasion process because it provides less interconnect area loss and reduces patterned edge roughness.

Cost Analysis:

$\begin{array}{ll}\text { Operating Expense } & \$ 0.30 \\ \text { Labor II } & \$ 0.25\end{array}$ (Etching supplies)


Process Step 3: Clean

An automatic glass sheet washing machine will be utilized in this step.

Cost Analysis:

$\begin{array}{ll}\text { Operating Expense } & \$ 0.20 \\ \text { Labor II } & \$ 0.10\end{array} \quad$ (Deionized water, detergent)

Process Step 4: Screen Print Conductive Paste

An automatic screen printing machine will be utilized in this step.

Cost Analysis:

$\begin{array}{lll}\text { Materials } & \$ 1.15 & \text { (Paste) } \\ \text { Operating Expense } & \$ 0.25 & \text { (Screens, chemicals, wipes) } \\ \text { Labor II } & \$ 0.25\end{array}$

Process Step 5: Temper Glass

This step will temper the module glass and fire the conductive paste in the same operation. Tempered module glass will eliminate the requirement for a rear glass sheet, thereby simplifying the encapsulation process. An automatic glass tempering system will be utilized to perform this dual operation.

Cost Analysis:

$\begin{array}{ll}\text { Operating Expense } & \$ 1.10 \\ \text { Labor I } & \$ 0.50\end{array}$ (Electricity,filters)

Process Step 6: Screen Print Maskant

An automatic screen printing machine will be utilized in this step.

Cost Analysis:

$\begin{array}{lll}\text { Materials } & \$ 0.40 & \text { (Paste) } \\ \text { Operating Expense } & \$ 0.20 & \text { (Screens, chemicals, wipes) } \\ \text { Labor I } & \$ 0.25\end{array} \quad$.

Process Step 7: Bake

An automatic belt oven will be utilized in this step. Cost Analysis:

$\begin{array}{ll}\text { Operating Expense } & \$ 0.30 \\ \text { Labor II } & \$ 0.25\end{array} \quad$ (Electricity)


Process Step 8: Deposit Amorphous Silicon Alloys

Process Step 9: Pattern Amorphous Silicon Alloys

Process Step 10: Deposit Rear Conductor

Process Step 11: Anneal

All of these process steps will be performed within an automated thin film materials processing system.

Cost Analysis:

$\begin{array}{lll}\text { Materials } & \$ 4.50 & \text { (Compressed gases, targets) } \\ \text { Operating Expense } & \$ 1.00 & \text { (Electricity) } \\ \text { Labor II } & \$ 1.00 & \end{array}$

Process Step 12: Remove Maskant

An automatic glass sheet washing machine will be utilized in this step.

Cost Analysis:

Operating Expense $\$ 0.25$ (Deionized water, brushes)

Labor II $\$ 0.25$

Process Step 13: Remove Shunts

An automatic shunt removal system will be utilized in this step.

Cost Analysis:

Labor II $\$ 0.25$

Process Step 14: Terminate

Soldering the terminals directly onto redesigned bus bars will eliminate the need for conductive ribbon. This operation will be performed by a soldering/assembly robot.

Cost Analysis:

$\begin{array}{lll}\text { Materials } & \$ 0.35 & \text { (Terminals, solder discs) } \\ \text { Labor II } & \$ 0.25\end{array}$

Process Step 15: Apply Encapsulant

An encapsulating material will be sprayed onto the rear surface of the module to provide a level of environmental resistance necessary for a twenty year outdoor life. This material will be applied by a spray process in an automated system. 
Cost Analysis:

$\begin{array}{lll}\text { Materials } & \$ 2.00 & \text { (Encapsulant) } \\ \text { Labor II } & \$ 0.25 & \end{array}$

Process Step 16: Cure Encapsulant

The encapsulant will be cured in an automatic UV/thermal conveyor oven.

Cost Analysis:

$\begin{array}{lll}\text { Operating Expense } & \$ 0.20 \\ \text { Labor II } & \$ 0.25\end{array}$

Process Step 17: Test

An automated solar simulator will be utilized in this step. Cost Analysis:

Labor II \$0.25 
Table 3 provides a listing of each process step, and Table 4 provides a summary cost analysis.

TABLE 3

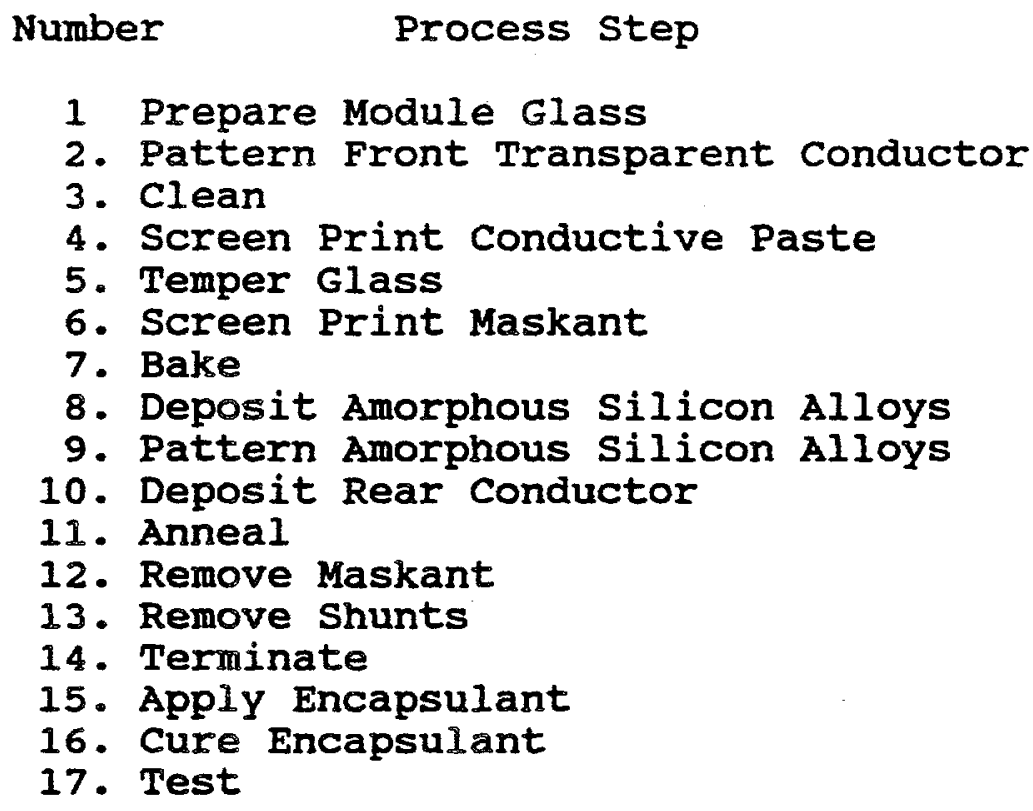

TABLE 4

SUMMARY COST ANALYSIS

\begin{tabular}{|c|c|c|c|c|}
\hline $\begin{array}{l}\text { Process } \\
\text { Step }\end{array}$ & Material & $\begin{array}{c}\text { Operating } \\
\text { Expense }\end{array}$ & Labor & Total \\
\hline $\begin{array}{l}1 \\
2 \\
3 \\
4 \\
5 \\
6 \\
7 \\
8,9,10,11 \\
12 \\
13 \\
14 \\
15 \\
16 \\
17\end{array}$ & $\begin{array}{l}\$ 8.10 \\
\$ 1.15 \\
\$ 0.40 \\
\$ 4.50 \\
\$ 0.35 \\
\$ 2.00\end{array}$ & $\begin{array}{l}\$ 0.20 \\
\$ 0.30 \\
\$ 0.20 \\
\$ 0.25 \\
\$ 1.10 \\
\$ 0.20 \\
\$ 0.30 \\
\$ 1.00 \\
\$ 0.25\end{array}$ & $\begin{array}{l}\$ 0.25 \\
\$ 0.25 \\
\$ 0.10 \\
\$ 0.25 \\
\$ 0.50 \\
\$ 0.25 \\
\$ 0.25 \\
\$ 1.00 \\
\$ 0.25 \\
\$ 0.25 \\
\$ 0.25 \\
\$ 0.25 \\
\$ 0.25 \\
\$ 0.25\end{array}$ & $\begin{array}{l}\$ 8.55 \\
\$ 0.55 \\
\$ 0.30 \\
\$ 1.65 \\
\$ 1.60 \\
\$ 0.85 \\
\$ 0.55 \\
\$ 6.50 \\
\$ 0.50 \\
\$ 0.25 \\
\$ 0.60 \\
\$ 2.25 \\
\$ 0.45 \\
\$ 0.25\end{array}$ \\
\hline & & $\$ 4.00$ & & \\
\hline
\end{tabular}


UPG'S future manufacturing cost of $\$ 24.85$ per module $(\$ 49.70$ per square meter) will represent $\$ 1.24$ per watt at an average stabilized total area conversion efficiency of $4 \%$, and $\$ 0.50$ per watt at an average stabilized total area conversion efficiency of $10 \%$.

Although designed for UPG's new production facility in 1994, implementation of UPG's future process into UPG's current module production facility would provide a cost reduction of $\$ 6.63$ per module without requiring an increase in production capacity. The bulk of this cost reduction is due to the elimination of the ribbon conductor, rear tempered glass, and the manual termination step. The manufacturing cost total would decrease to $\$ 19.14$ per module, and the per watt cost would decline $\$ 1.65$ to $\$ 4.79$ per watt. 
TASK 3 OBSTACLES TO ACHIEVING UPG'S FUTURE PROCESS

The primary obstacle faced by UPG toward achieving the described future process is the lack of available capital to finance the establishment of a new production facility and the purchase of the required manufacturing equipment. Secondary obstacles are technical uncertainties and are itemized as the following questions:

1. Can module glass tempering and firing of conductive paste be performed in the same operation?

2. Can a high efficiency automated solder/assembly machine be built to perform the high quality one-step termination procedure?

3. Can a spray-on encapsulation material provide the same level of module reliability as the glass/EVA/glass package?

It is also important to identify issues which are not considered to be obstacles to UPG's future process:

1. Increase in module area from 0.10 square meters to 0.5 square meters.

2. Acquisition of fully automated manufacturing equipment not identified previously as an obstacle.

3. Patterning of the front transparent conductor by an electrochemical printing operation.

The above mentioned obstacles faced by UPG may be "generic" obstacles faced by the entire US PV industry. The lack of capital is definitely an industry wide problem since even those US PV companies which are part of large, profitable firms have difficulty in securing expansion capital. Termination and encapsulation processes and their automation are probably generic issues as well, since currently used processes are often cited as factors in module reliability related failures and as important factors in cost reduction. 
Strategies to eliminate the capital availability obstacle are beyond the scope of the PVMaT program except to the extent that the elimination of the technical obstacles may have an effect on the availability of expansion capital.

The three technical obstacles identified in TASK 3 can be overcome with a focused process engineering development program. This program will involve materials evaluation, machine design and construction, and the participation of certain suppliers of materials and equipment. success of this program in a timely and cost effective manner will require an "open" program philosophy, in which the technological issues and goals are discussed openly with suppliers, competitors, and anyone outside of UPG who may be able to assist with the program. Unproductive philosophies such as those typified by the phrases "Not invented here" and "It's proprietary" will only serve to decrease the probability of the program's success. With an open philosophy in mind, UPG will take the following approaches towards elimination of the technical obstacles:

1. Can module glass tempering and firing of conductive paste be performed in the same operation?

UPG will utilize the expertise of a supplier of glass tempering equipment to answer this technical question, since UPG does not possess a glass tempering system and the supplier not only has a vast knowledge of glass tempering, but also has a great interest in selling their systems to PV companies. UPG will provide module glass with its patterned transparent conductor and screen printed conductive paste bridge conductors/bus bars to the tempering system supplier. The suppliers will develop the tempering process and UPG will evaluate post tempering glass quality by processing the module to completion. Several iterations of this procedure may be required if changes in module design or materials are necessary.

2. Can a high efficiency automated solder/assembly machine be built to perform the high quality one-step termination procedure?

UPG will design and build a prototype solder/assembly machine using off-the-shelf robotic components to demonstrate the quality and performance of the one-step automatic termination procedure. The prototype machine will not provide optical registration, automatic module loading, and will not be ale to attach both terminals at the same time. 
3. Can a spray-on encapsulation material provide the same level of module reliability as the glass/EVA/glass package?

UPG will survey all commercially available materials for their suitability as encapsulants, including silicones, urethanes, and epoxies. Suppliers of equipment to apply these materials will be utilized to demonstrate the performance of their equipment, and UPG will conduct a series of accelerated reliability tests on all candidate materials. PV modules fabricated with the tempered front glass and onestep termination processes will be encapsulated with the selected materials, and will undergo reliability testing. Reliability testing will serve to document the effect of these process changes on overall module reliability.

\section{CONCLUSIONS}

UPG'S PVMaT Phase I report contains the result of a manufacturing technology cost analysis based upon an existing PV module production facility. It also projects the cost analysis of a future production facility based upon larger module area, larger production rate, and the elimination of several technical obstacles. With a coordinated eighteen month engineering effort the technical obstacles could be overcome. Therefore, if solutions to the financial obstacles concerning production expansion were found, UPG would be able to manufacture PV modules at a cost of under $\$ 1.25$ per watt by 1994 . 


\begin{tabular}{|c|c|c|c|}
\hline $\begin{array}{c}\text { Document Control } \\
\text { Page }\end{array}$ & $\begin{array}{l}\text { 1. SERI Roport No. } \\
\text { SERI/TP-214-4482 }\end{array}$ & $\begin{array}{l}\text { 2. NTIS Accession No. } \\
\text { DE92001169 }\end{array}$ & 3. Recipient's Accession No. \\
\hline \multirow{2}{*}{\multicolumn{3}{|c|}{$\begin{array}{l}\text { 4. Title and Subtitle } \\
\text { Photovoltaic Manufacturing Technology Phase } 1\end{array}$}} & $\begin{array}{l}\text { 5. Publication Date } \\
\text { November } 1991\end{array}$ \\
\hline & & & 6. \\
\hline \multicolumn{3}{|l|}{$\begin{array}{l}\text { 7. Author(s) } \\
\text { M. J. Stern }\end{array}$} & 8. Performing Organization Rept. No. \\
\hline \multirow{2}{*}{\multicolumn{3}{|c|}{$\begin{array}{l}\text { 9. Performing Organization Name and Address } \\
\text { Utility Power Group } \\
\text { Chatsworth, California }\end{array}$}} & $\begin{array}{l}\text { 10. Project/Task/Work Unit No. } \\
\text { PV150101 }\end{array}$ \\
\hline & & & $\begin{array}{l}\text { 11. Contract (C) or Grant (G) No. } \\
\text { (C) XC-1-10057-6 } \\
\text { (G) }\end{array}$ \\
\hline \multirow{2}{*}{\multicolumn{3}{|c|}{$\begin{array}{l}\text { 12. Sponsoring Organization Name and Address } \\
\text { National Renewable Energy Laboratory } \\
1617 \text { Cole Blvd. } \\
\text { Golden, Colorado } 80401-3393\end{array}$}} & $\begin{array}{l}\text { 13. Type of Report \& Period Covered } \\
\text { Technical Report }\end{array}$ \\
\hline & & & 14. \\
\hline \multicolumn{4}{|c|}{$\begin{array}{l}\text { 15. Supplementary Notes } \\
\text { NREL Technical Monitor: R. Mitchell, (303) 231-1379 }\end{array}$} \\
\hline \multicolumn{4}{|c|}{$\begin{array}{l}\text { 16. Abstract (Limit: } 200 \text { words) } \\
\text { This report documents Utility Power Group's (UPG) contract under Phase } 1 \text { of the Photovoltaic Manufacturing } \\
\text { Technology (PVMaT) project. Specifically, the report contains the results of a manufacturing technology cost } \\
\text { analysis based on an existing PV module production facility. It also projects the cost analysis of a future } \\
\text { production facility based on a larger module area, a larger production rate, and the elimination of several technical } \\
\text { obstacles. With a coordinated } 18 \text {-month engineering effort, the technical obstacles could be overcome. Therefore, } \\
\text { if solutions to the financial obstacles concerning production expansion were found, UPG would be able to } \\
\text { manufacture PV modules at a cost of under } \$ 1.25 \text { per watt by } 1994 \text {. }\end{array}$} \\
\hline \multirow{2}{*}{\multicolumn{4}{|c|}{$\begin{array}{l}\text { 17. Document Analysis } \\
\text { a. Descriptors } \\
\text { photovoltaic modules ; thin films ; manufacturing ; photovoltaics ; solar cells } \\
\text { b. Identiflers/Open-Ended Terms }\end{array}$}} \\
\hline & & & \\
\hline \multirow{2}{*}{\multicolumn{3}{|c|}{$\begin{array}{l}\text { 18. Availability Statement } \\
\text { National Technical Information Service } \\
\text { U.S. Department of Commerce } \\
5285 \text { Port Royal Road } \\
\text { Springfield, VA } 22161\end{array}$}} & $\begin{array}{l}\text { 19. No. of Pages } \\
22\end{array}$ \\
\hline & & & $\begin{array}{l}\text { 20. Price } \\
\text { A03 }\end{array}$ \\
\hline
\end{tabular}

Form No. 0069E (6-30-87) 